\title{
Up the magnetic pressure
}

\author{
磁気圧を上げる
}

Shaun Fisher and George Pickett

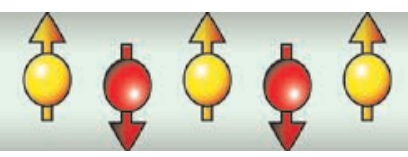

超流動へリウムの磁気噴水効果を観察することは、実験として美しいだけでなく、ほかの多くの 不思議な磁気現象を研究するための手段にもなる。

Nature Vol.444(832-833)/14 December 2006

ヘリウムの軽い同位体である ${ }^{3} \mathrm{He}$ は、絶対零度からわ ずか数ミリ Kという温度で液体の状態にあり、超流動 体として奇妙な性質を示し始める ${ }^{1}$ 。興味深いことに、 こうした超流動状態では、質量だけでなく磁気も摩擦 なく移動することができる。Nature 12 月 14 日号 909

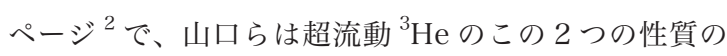
間の相互作用を利用して、圧力をかけることで磁気を 誘導し、磁気をかけることで圧力を誘導する装置を開 発したと報告している。

液体が摩擦なしに流れる超流動は、巨視的な数の粒子 が系の最低のエネルギー状態（基底状態）を占めるときに 起こる。ひとたびこうした「凝縮」が起こると、粒子は 1 つの量子力学的実体として集合的に振る舞うようになり、 自由に流水始める。凝縮のしかたは、撖密には、粒子の量 子力学的な種類によって決まってくる。粒子は、そのスピ ン角運動量（単に「スピン」という）に応じて、ボース粒 子とフェルミ粒子の 2 つ分類することができる。ボース 粒子は作用量子（プランク定数 $\mathrm{h}$ をある数で割つたもので あり、んと表記する) の整数倍のスピンをもち、フェルミ 粒子は作用量子の半奇数倍のスピンをもつ。原子を構成 する電子や陽子や中性子は、いずれもフェルミ粒子である。

最も単純な超流動は、ボース粒子がボースーアインシュ タイン凝縮という過程を経ることにより形成される。一般 的な例は、 ${ }^{4} \mathrm{He}$ が約 $2 \mathrm{~K}$ 以下の温度で示す超流動である ${ }^{3}$ 。 ${ }^{4} \mathrm{He}$ 原子は、半奇数スピンをもつ 4 個の核子 (2 個の陽 子と 2 個の中性子）と、その周りをまわる半奇数スピンを もつ 2 個の電子からできている。これらのスピンをたし合 わせると原子全体ではスピンがゼロになるため、 ${ }^{4} \mathrm{He}$ 原子 はボース粒子ということになる。超低温希薄気体では、よ り理想的なボースーアインシュタイン凝縮が起こる4。
${ }^{4} \mathrm{He}$ とは対照的に、奇数個の核子 (2 個の陽子と 1 個の 中性子）からなる ${ }^{3} \mathrm{He}$ は、原子全体ではスピンが半奇数 になるため、フェルミ粒子ということになる。ボース粒子 とは異なり、フェルミ粒子はパウリの排他律という法則に 従っており、複数の粒子が同一の量子状態をとることが できない。だとすると、フェルミ粒子が凝縮して超流動 を起こすことはないように思われる。けれどもフェルミ粒 子は、低温で対になって整数スピンのボース粒子を形成 し、それが凝縮を起こす可能性がある。このような対凝 縮が固体中の伝導電子で起きたものが超伝導である。最 近になって、ある種の超低温原子気体でも同様の凝縮が 起こることが実証された ${ }^{5}$ 。

液体 ${ }^{3} \mathrm{He}$ 中では、数ミリ K以下の温度で起こる凝縮が、 超流動体に奇妙な振舞いをさせている。凝縮対のスピン はゼロではなく、特定の方向を向く軌道角運動量もゼロで はない。この第2の性質が、液体に方向性を与える。つまり、 角運動量の向きに対して水平な方向への擾乱と垂直な方 向への擾乱に対して、液体が異なる応答をするのである。 こうした向きは液体中の領域ごとに異なっていることがあ り、運動量の「織目」を生じさせる。凝縮対は質量だけで なくスピンと軌道角運動量ももっているため、ある条件に おいては、 ${ }^{3} \mathrm{He}$ の超流動性とは、この 3 つの物性のすべ てについて摩擦なく流れることであるといってよい ${ }^{6}$ 。 ピンは粒子の磁気的応答と密接に関係しているため、超 流動 ${ }^{3} \mathrm{He}$ では磁化も摩擦なしに移動することになる。

山口ら ${ }^{2}$ は、 ${ }^{3} \mathrm{He}$ のこうした性質を利用して、ほかの超 流動体でみられる奇妙な熱 - 機械現象を、磁気について 初めて実証することに成功した。この現象は一般には噴 水効果として知られており、絶対零度よりも高い温度で 一部の原子が熱的に励起して高いエネルギー準位に移る 


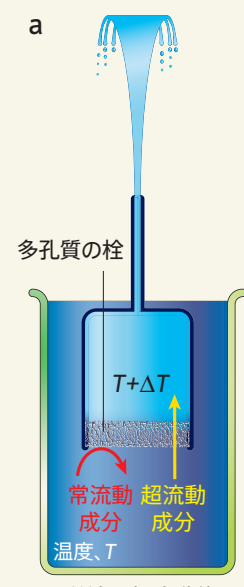

単純な超流動体

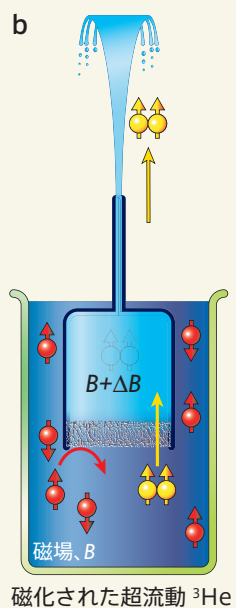

図1 磁気噴水効果

a. 単純なボース粒子の超流動体 $\left({ }^{4} \mathrm{He}\right.$ など) では、凝縮し た超流動成分と常流動成分が混ざり合っている。液体の流れ を制限する多孔質の栓（スーパーリーク）を挟んで温度勾配 $\Delta T$ をかけると、超流動成分は温度差をなくすために栓を通 過して移動していくが、粘度がある常流動成分はここでせき 止められてしまう。その結果、超流動成分の「噴水」ができる。 b. ${ }^{3} \mathrm{He}$ では、超流動成分は原子対（黄色）を形成している。 これは、 ${ }^{3} \mathrm{He}$ 原子がフェルミ粒子であるため、単独で疑縮し て超流動状態になることができないからである。山口ら ${ }^{2}$ が 調べた ${ }^{3} \mathrm{He}$ の $\mathrm{A}_{1}$ 相では、超流動対が強く磁化され、そのス ピンが強磁場に沿って整列しているのに対して、対をなして いない原子 (赤) は磁化されていない。このとき、磁化され たスピンの対が移動して、磁場勾配 $\Delta B$ が作り出す磁化の差 をなくそうとすることで、磁気噴水効果を生じさせる。
ときに起こる。これらの原子は凝縮体の一部ではないた め、粘度がゼロではない、古典的な常流動成分となる（基 本的に、粘度は液体が生み出す摩擦抵抗力の尺度になる)。

常流動成分と超流動成分が混ざり合ったこのような液 体に圧力勾配をかけて、細い管や多孔質の栓から押し出 すことを考えてみよう。粘度がゼロの超流動成分はこの 部分も自由に通過できるのに対して、常流動成分は粘度 があるため通過することができない。この栓はスーパー リークとよばれ、常流動成分を除去するフィルターの役 割を果たしている。凝縮した超流動成分は熱エネルギー をもたないため、栓を通過してきた部分の液体の温度は 低くなる。これに対して、栓を通過していない部分の液 体では、熱的に励起した常流動成分の比率が高くなるた め、温度も高くなる。圧力勾配をかけることで栓をはさ んだ液体に温度勾配を生じさせるこのような機械一熱効 果は、超流動 ${ }^{4} \mathrm{He}$ ではよく知られている。噴水効果は これとは逆の現象であり、スーパーリークを挟んで温度 勾配をかけたときに起こる。この温度差をなくすために 超流動成分が移動して流れが生じ、この圧力差を上に向 けるときに噴水ができるのである ${ }^{3}$ (図 1a)。

山口らが今回観察した磁気噴水効果には、強磁場のも とでのみ存在する超流動 ${ }^{3} \mathrm{He}$ の $\mathrm{A}_{1}$ 相とよばれる状態が 関係している。A 1 相では、超流動成分の凝縮原子対のす ベてが磁場に沿ってスピンを整列させるが、対をなして いない原子ではそのようなことは起こらない。スーパー リークは強く磁化された超流動成分だけを通過させるこ とにより、スピンフィルターとして機能する。スーパーリー クをはさんだ圧力差によって生じる機械的な流れは、こ こを通過した液体をさらに強く磁化させる。逆に、磁場 勾配により生じた磁化の差は、スーパーリークを挟んだ 圧力差を生じさせることになる。これは、磁化の差をな くそうとして超流動体が移動するからである（図 1b)。
こうした実験 ${ }^{2}$ は、非常に強い磁場と非常に低い温度 の中での高感度の測定を必要とする。磁気噴水効果を観 察した著者らはさらに、同じ装置を利用して磁化が緩和 する過程について調べた。磁化の緩和は、噴水の圧力の 低下として反映され、半透膜の変形を通じて測定するこ とができる。興味深いことに、著者らが得た知見は、事 前の予想に反していた。すなわち、液体へリウムの超流 動 $\mathrm{A} 1$ 相は完全には磁化されておらず、凝縮対の一部は磁 場の向きとは逆の方向を向いているようなのである。だと すると、 $\mathrm{A}_{1}$ 相の性質について広く受け入れられている単 純化された概念は、改めなければならないかもしれない。

磁気噴水効果は、機械的スピンフィルターの美しい実 演になるだけでなく、強磁場における磁化の緩和などの 広範な磁気現象を調べるための便利な道具にもなりうる だろう。将来的には、この系や類似の電気系に基づく応 用技術にも大いに期待することができる。一部の風変わ りな超伝導体は超流動 ${ }^{3} \mathrm{He}$ に似た構造をもっているため、 これらも磁気噴水効果を示す可能性がある。このような 材料を組み込んだ素子を作製することができれば、外部 から与えられる磁場などの大きさに応じて摩擦なしにスピ ンを操作する素子なども考えることができる。このような 性質は、急速に拡大しつつあるスピン電子工学の分野に、 各種の新しい素子や微小機械をもたらすだろう。

Shaun Fisher and George Pickett、ランカスター大学（英）

1. Volovik, G. E. Exotic Properties of Superfluid ${ }^{3} \mathrm{He}$ (World Scientifc, Singapore, 1992).

2. Yamaguchi, A., Kobayashi, S., Ishimoto, H. \& Kojima, H. Nature 444, 909-912(2006).

3. Guénault, A. M. Basic Superfluids (Taylor \& Francis, London, 2003).

4.Anderson, M. H., Ensher, J. R., Matthews, M. R., Wieman, C. E. \& Cornell, E. A Science 269, 198-201(1995).

5. Zwierlein, M. W., Schunck, C. H., Schirotzek, A. \& Ketterle, W. Nature 442 54-58(2006).

6. Fisher, S.N. \& Suramlishvili, N. J. Low Temp. Phys. 141, 111-141(2005). 